\title{
EVALUATION OF TEACHERS' TECHNOLOGICAL PEDAGOGICAL CONTENT KNOWLEDGE WITHIN THE FRAMEWORK OF EDUCATIONAL INFORMATION NETWORK AND OTHER VARIABLES
}

\author{
Dr. Kamil CEKEROL \\ ORCID:0000-0002-9034-9470 \\ Open Education Faculty, Anadolu University \\ Eskisehir, TURKEY \\ Emin OZEN \\ ORCID: 0000-0001-7026-1503 \\ Distance Education, Anadolu University \\ Eskisehir, TURKEY
}

Received: 01/10/2019 Accepted: 10/05/2020

\begin{abstract}
The aim of this study is to examine the relationship between Technological Pedagogical Content Knowledge (TPACK) of teachers teaching at different levels of educational institutions and demographic information about them as well as their technology and Educational Information Network (EIN) use. The participants of the study were determined by using stratified sampling method from the teachers teaching in staterun primary schools, secondary schools and high schools in Eskisehir in Turkey. 364 teachers voluntarily participated in the study by filling out the data collection tool. The first part of the survey includes questions to collect demographic data about the participants as well as the ones related to their technology and EIN use. The second part involves TPACK scale developed by Horzum, Akgun and Ozturk (2014). According to the results of the statistical analysis, the teachers find themselves competent in terms of TPACK factors and there are significant differences between TPACK factors and demographic information about the participants as well as their technology and EIN use. It is believed that increasing technology knowledge of teachers will also improve their pedagogy and content knowledge. Therefore; it is suggested that more studies should be conducted which combine technology, pedagogy and content knowledge.
\end{abstract}

Keywords: Technological pedagogical content knowledge, TPACK, use of technology, educational information network.

\section{INTRODUCTION}

Teachers should have various competencies beyond their content knowledge so that they can teach effectively. The educator who dealt with these competencies for the first time within the framework of "pedagogical content knowledge" was Shulman (1986) (Yilmaz, 2015). According to this theoretical framework, teachers should be equipped with considerable amount of content and pedagogy knowledge so that they can teach course contents effectively. Due to technological advancements, it is acknowledged that pedagogical content knowledge is not enough for effective teaching, so technological knowledge has been considered a new teaching competence since then. Effective and efficient use of blackboard, whiteboard, projector, computer and interactive board in educational environments is important as part of the current efforts to integrate technology into education to achieve higher quality (Akyuz, Kurnaz, Pektas \& Memis, 2014). In addition, technology knowledge includes not only the use of technological devices but also all other devices, methods and processes as well as management and control mechanisms which function like a bridge between scientific knowledge and practice (Alkan, 1998). Thus, content, pedagogy and technology knowledge as well as their relationships with each other become important issues when teacher competencies are considered. 
The structure that involves technology, pedagogy and content knowledge is called Technological Pedagogical Content Knowledge (TPACK). This term was suggested by Mishra and Koehler (2007) by extending Pedagogical Content Knowledge (PCK), which was coined by Shulman in 1986, to include educational technologies as well (Canbolat, 2011). Technological Pedagogical Content Knowledge (TPACK) is a theoretical framework developed in order to define teachers' technological pedagogical content knowledge in regard to effective interaction between technology and education.

Each component of TPACK is defined as follows (Koehler \& Mishra, 2008): Content knowledge refers to the knowledge to be taught and learned. Pedagogy knowledge is not about the content to be taught but about how this content is taught, and the methods and strategies applied in the classrooms. Technology knowledge is the knowledge teachers have regarding the use of technological devices ranging from the standard ones such as blackboard and chalk to advanced technological devices such as computers. Technological content knowledge is about which technology is appropriate and what technology offers as opportunities and limitations while teaching the content. Pedagogical content knowledge refers to the knowledge about how a particular content should be taught. Technological pedagogical knowledge covers all kinds of knowledge about how technological devices are used in educational practices and how educational processes change with technology use. Technological pedagogical content knowledge (TPACK) refers to the knowledge about how technology can be used to teach a particular content through various constructive methods, develop new theories, strengthen already existing theories and clarify the meanings of complex concepts.

Effective technology integration requires knowledge about the relationships between content, technology and pedagogy knowledge because none of them is sufficient itself for the realization of effective learning (Koehler, Misra \& Yahya, 2007). In addition to the necessity of having sufficient amount of content, technology and pedagogy knowledge, it is essential that these types of knowledge should be combined effectively (Perkmen $\&$ Tezci, 2011).

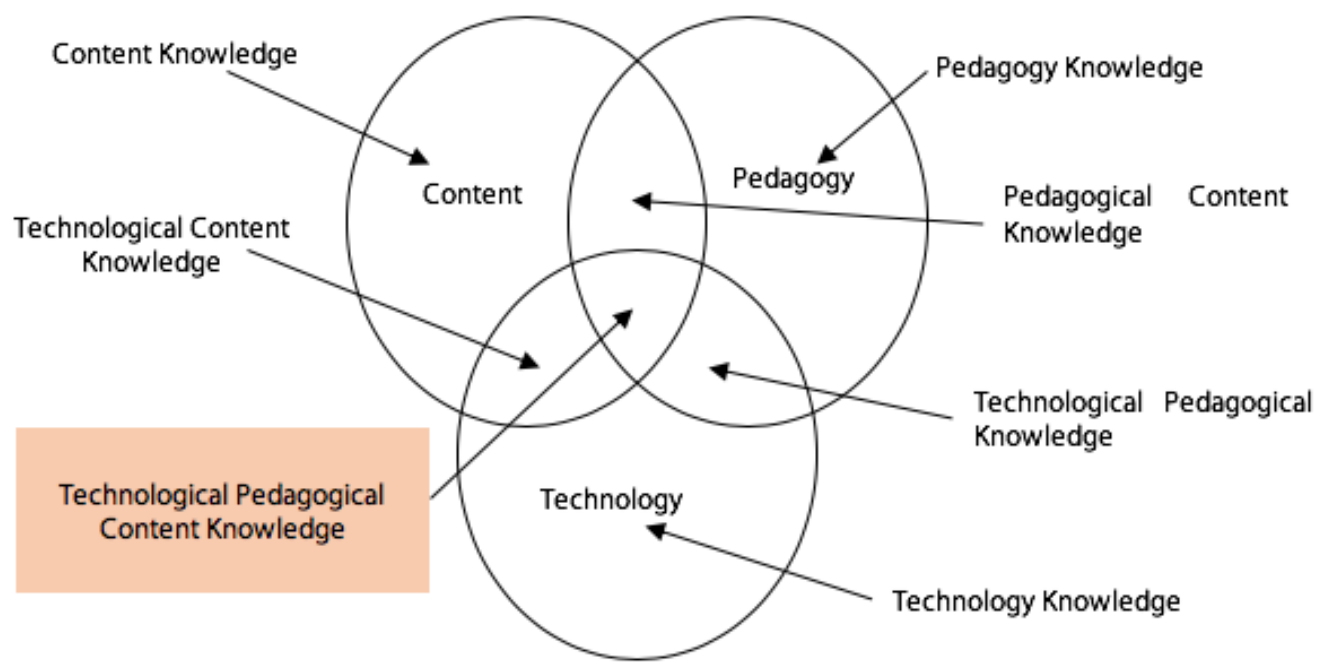

Figure 1. TPACK framework and knowledge components (Koehler and Mishra, 2008)

Technological pedagogical content knowledge (TPACK), which is the intersection of content, pedagogy and technology, is the knowledge about the combination of necessary pedagogical strategies, methods and techniques to teach a particular content by using technology (Koehler \& Mishra, 2008, p.12).

Just like other fields, technological developments considerably affect the field of education as well. Use of technology in education is becoming more and more popular in educational institutions because teaching and learning process are more efficient and motivating thanks to technological developments (Temizyurek \& Unlu, 2015). In this respect, Turkish Ministry of Education established EIN program in 2011 to integrate new educational approaches to educational practices (Ozen, 2019). 
Effective use of technology in education has a positive effect on academic achievement (Teo, Ursavas \& Bahcekapili, 2012). Advancements in technology bring about some changes in students' learning, which, in turn, requires teachers to update their knowledge and competencies accordingly. Therefore, it is essential to measure teachers' and preservice teachers' techno-pedagogical educational competencies. TPACK is considered an appropriate model to develop a scale aiming to measure and evaluate teachers' and preservice teachers' background knowledge about technology integration (Onal, 2016). In the literature, there are studies that examine how successful educators use content, pedagogy and technology knowledge in educational processes as well as those which are conducted to develop new scales integrated to TPACK or adopt already existing scales (Balcin \& Ergun, 2018; Bagdiken \& Akgunduz, 2018; Yarar, 2018; Ay, 2015; Karadeniz \& Vatanartiran, 2015; Ay, Karadag, \& Acat, 2015; Kartal, Kartal, \& Uluay, 2016). These studies generally focus on determining TPACK competencies of teachers from various disciplines and educational levels and examining the correlations between TPACK and various variables (Yilmaz, 2015).

This study is expected to contribute to the literature by presenting findings related to the effects of "access to technology", "participation in in-service training programs" and "demographic information about participants such as gender, teaching specialization, age, duration of working and institution" on TPACK levels and by combining EIN use and TPACK framework. Therefore, this study aims to determine technological pedagogical content knowledge of primary school, secondary school and high school teachers in Eskisehir - a city located in Turkey-, to examine whether TPACK factors differ according to demographic variables as well as various variables related to technology and EIN use and, finally, to offer some suggestions for further practices and studies under the light of these findings. As a result, this study tries to answer the following questions:

1. What is the level of teachers' technological pedagogical content knowledge (TPACK)?

2. Do TPACK levels of teachers differ according to gender, teaching specialization, age and educational institution levels?

3. Do TPACK levels of teachers differ according to "access to technology", "technological competencies" and "participation in in-service training programs"?

4. Do TPACK levels of teachers differ according to EIN use levels of teachers?

\section{METHOD}

The study used cross-sectional survey method, which is a quantitative research method (Buyukozturk et.al, 2012). This method aims to examine a situation by collecting data at one time and exploring the relationships among variables (Baris, 2015).

\section{Participants}

The population of the study is the teachers working in state-run schools in Eskisehir (primary schools, secondary schools and high schools) in 2018-2019 academic year. The study group consists of 364 teachers chosen from different regions and districts through stratified sampling method. This method is used when units of the population differ in terms of their characteristics, and units are classified under sub-groups called strata according to certain criteria. Here, study group is determined by randomly choosing samplings for each strata (Kilic, 2013). The demographic information about the participants is displayed in Table 1 and the data about their technology use in Table 2. 
Table 1. Information about teachers' gender, teaching branch, age and institution

\begin{tabular}{|c|c|c|c|c|c|c|c|}
\hline Characteristics & & $\mathrm{n}$ & $\%$ & Characteristics & & $\mathrm{n}$ & $\%$ \\
\hline \multirow[t]{4}{*}{ Gender } & Female & 228 & 62.6 & Institution & Primary School & 95 & 26.1 \\
\hline & Male & 136 & 37.4 & & Secondary School & 202 & 55.5 \\
\hline & Total & 364 & 100 & & High School & 67 & 18.4 \\
\hline & & & & & Total & 364 & 100 \\
\hline \multirow[t]{5}{*}{ Age } & $<30$ & 23 & 6.3 & Teaching & Social Science courses & 137 & 37.6 \\
\hline & $30-39$ & 194 & 53.3 & Specialization & Science courses & 106 & 29.1 \\
\hline & $40-49$ & 114 & 31.3 & & Basic Education & 83 & 22.8 \\
\hline & $>50$ & 33 & 9.1 & & Sport/Art & 38 & 10.4 \\
\hline & Total & 364 & 100 & & Total & 364 & 100 \\
\hline
\end{tabular}

According to Table 1, most of the participants are female ( $\mathrm{n}=228, \%$ 62.6), within 30 - 39 age range $(\mathrm{n}=194, \% 53.3)$, secondary school teachers $(\mathrm{n}=202, \% 55.5)$ and teach a social science course $(\mathrm{n}=137$, \%37.6). Subjects taught in these schools were classified as follows: social science courses (geography, religion, literature, social sciences, Turkish, foreign language and special education); science courses (science, mathematics, technology); sport-art courses (physical education, visual arts, music); basic education courses (class teachers and pre-school teachers).

The data about participants' EIN use and technology knowledge were collected in the first part of the data collection tools. The related questions and the distribution of the replies are presented in Table 2 . Accordingly, majority of the teachers $(\mathrm{n}=296, \% 81.3)$ have access to the internet in their schools, label their technological competencies as "good" ( $\mathrm{n}=183, \% 50.3)$, have received in-service training about technology use $(n=249, \% 68.4)$ and use EIN when needed $(n=309, \% 84.9)$.

Table 2. The data about teachers' technology knowledge and EIN use

\begin{tabular}{llrrllrr}
\hline Characteristics & & $\mathrm{n}$ & $\%$ & Characteristics & & $\mathrm{n}$ & $\%$ \\
\hline In your institution, & Yes & 296 & 81.3 & Have you received & Yes & 249 & 68.4 \\
can you access the & No & 60 & $16.5 \begin{array}{l}\text { any in-service training } \\
\text { about technology }\end{array}$ & No & 109 & 29.9 \\
technology you need? & Total & 356 & 97.8 use? & Total & 358 & 98.4 \\
& & & & & & & \\
How do you define your & Very good & 44 & 12.1 & How do you define & Regularly & 39 & 10.7 \\
technology use level? & Good & 183 & 50.3 & your EIN use? & When needed & 309 & 84.9 \\
& Poor & 6 & 1.7 & Never & 16 & 4.4 \\
& Total & 363 & 99.7 & Total & 364 & 100 \\
\hline
\end{tabular}

\section{The Data Collection Tool}

The data for the study were collected through a survey which was administered face to face. The first part of the survey includes questions aiming to collect demographic data and the data regarding the technology use of the participants. In the second part of the survey, "Technological Pedagogical Content Knowledge Scale" developed by Horzum, Akgun and Ozturk (2014) was used after getting necessary permissions from the researchers. This 51-item scale has 7 factors: "Technology Knowledge", "Content Knowledge", "Pedagogy Knowledge", "Pedagogical Content Knowledge", "Technological Content Knowledge", "Technological Pedagogical Knowledge" and "Technological Pedagogical Content Knowledge". The scale has 5-point Likert scale format (1: I do not agree at all, 5: I totally agree). Table 3 below presents internal consistency coefficients obtained both in the original study and the current study. According to these values, "Technological Pedagogical Content Knowledge Scale" is a reliable data collection tool. 
Table 3. Reliability of Technological Pedagogical Content Knowledge Scale

\begin{tabular}{lccc}
\hline Factors & Number of Items & $\begin{array}{c}\text { The a value in the } \\
\text { adaptation study }\end{array}$ & $\begin{array}{c}\text { The a value in the } \\
\text { current study }\end{array}$ \\
\hline Technology Knowledge & 6 & .85 & .90 \\
Pedagogy Knowledge & 7 & .82 & .86 \\
Content Knowledge & 8 & .85 & .93 \\
Technological Content Knowledge & 6 & .84 & .88 \\
Pedagogical Content Knowledge & 8 & .87 & .76 \\
Technological Pedagogical Knowledge & 8 & .89 & .93 \\
Technological Pedagogical Content & 8 & .88 & .93 \\
Knowledge & & & .93 \\
\hline
\end{tabular}

\section{Data Analysis}

The responses provided for 51 items in this 5-point Likert type scale were interpreted by determining factor points for each factor by using SPSS ${ }^{\circledR}$ StatisticsSubscription program. The data obtained were analyzed by using descriptive statistics such as frequency, percentage, and means etc. Independent samples t-test was used for the following analyses: changes in Technological Pedagogical Content Knowledge according to the variables; paired comparisons for "gender", "access to technology" and "receiving in-service training on technological issues" variables. One-way ANOVA was used for all other variables. Finally, Post Hoc tests were used depending on homogeneity of variance distribution in order to determine which groups account for significant differences between the groups obtained from variance analyses. The results were tested at $\mathrm{p}<.05$ degree of significance.

\section{FINDINGS}

The findings from the analyses regarding TPACK sub-factors according to demographic data about the participants as well as the data about their technology use and EIN use are presented below.

\section{Findings Regarding Teachers' Technological Pedagogical Content Knowledge}

Teachers' perceptions about their technological pedagogical content knowledge are displayed in Table 4 below. When the means of the responses provided for 5-point evaluation are considered, it is seen that means are generally high and these high scores are quite close to 5 , which is the maximum score. Although the lowest mean was calculated for "technology knowledge" component, it can be said that teachers find themselves competent in terms of TPACK and all its components.

Table 4. Teachers' Technological Pedagogical Content Knowledge

\begin{tabular}{lcc}
\hline Factors & $\overline{\mathrm{X}}$ & $\mathrm{ss}$ \\
\hline Technology Knowledge & 3.74 & 0.67 \\
Pedagogy Knowledge & 4.12 & 0.52 \\
Content Knowledge & 4.25 & 0.58 \\
Technological Content Knowledge & 3.93 & 0.62 \\
Pedagogical Content Knowledge & 4.20 & 0.57 \\
Technological Pedagogical Knowledge & 4.04 & 0.62 \\
Technological Pedagogical Content Knowledge & 4.03 & 0.62 \\
\hline
\end{tabular}




\section{Findings Regarding Demographic Variables Affecting Teachers' Technological Pedagogical Content Knowledge}

The data regarding study-specific demographic variables, which are gender, teaching specialization, age, institution, are presented below.

\section{Findings Regarding "Gender and Specialization" Variables}

Teachers' technology knowledge, which is a factor of TPACK, significantly differs according to gender (sig. $=.015<.05)$. Male teachers' perception about technology $(\overline{\mathrm{X}}=3.85)$ is higher than female teachers $(\overline{\mathrm{X}}$ $=3.67)$.

One-way ANOVA was used to identify whether TPACK factors differ according to teaching specialization, age, duration of work and educational institutions variables. The ones with significant differences are displayed in Table 5 below.

Table 5. ANOVA results regarding TPACK and teaching branch variable

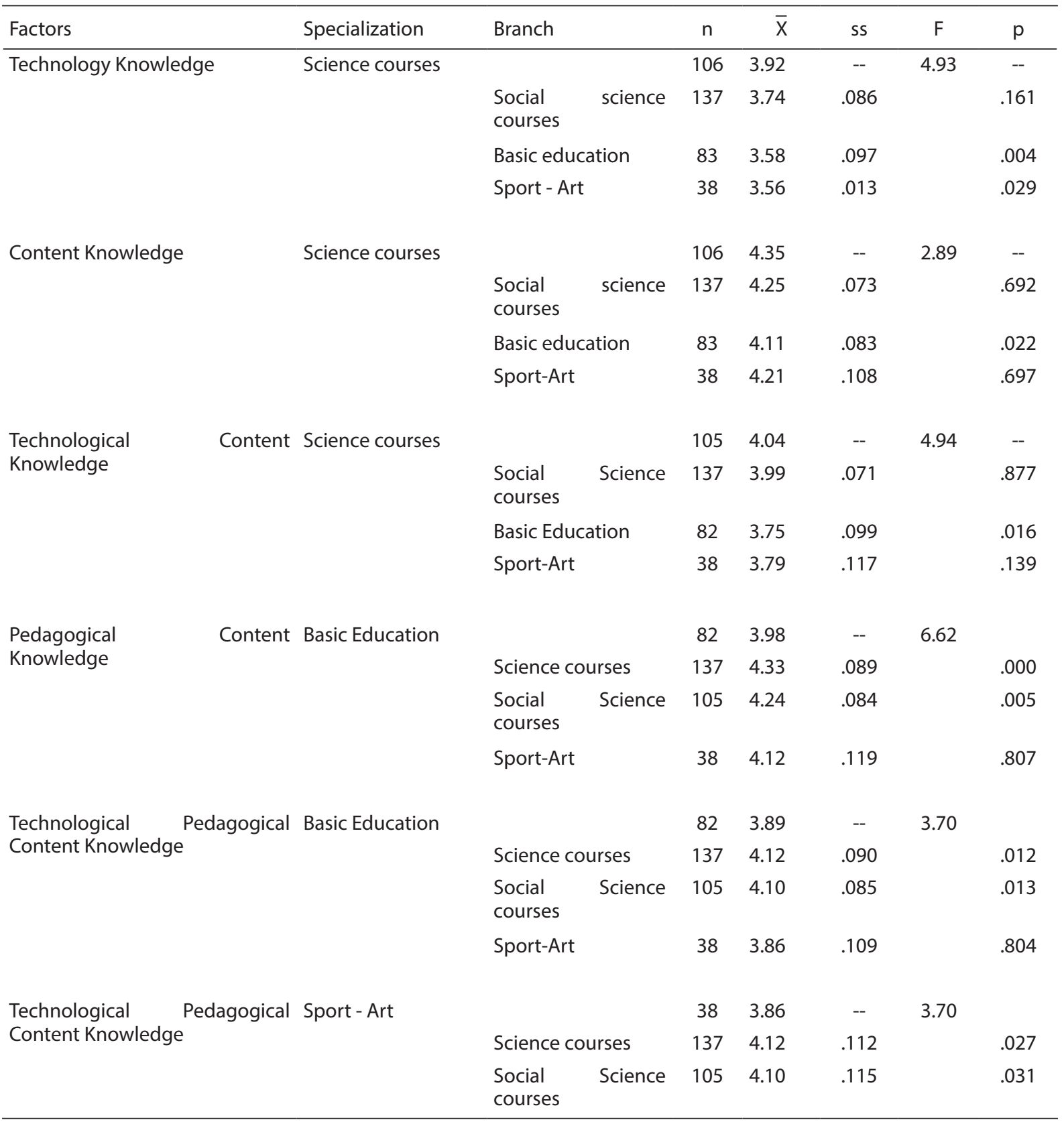


A significant difference was found between teachers' teaching specializations and their Technology Knowledge $\left(\mathrm{F}_{(3-364)}=4.93\right.$, sig:.002<.05). Since variances were distributed homogenously (sig:.208>.05) and the distribution in sampling groups was not equal, Hochberg's GT2 Post Hoc test was used. According to the results of the test, there is a significant difference between science courses teachers and basic education teachers (sig:.004<.05) and sport-art teachers (sig:.029<.05) in terms of technology knowledge. In addition, science courses teachers $(\bar{X}=3.92)$ find themselves more competent than teachers in other specializations in terms of technology knowledge.

According to the study, there is a significant difference in Content Knowledge according to teachers' teaching specializations $\left(\mathrm{F}_{(3-364)}=2.89\right.$; sig:.035<.05). Since variances were homogenously distributed (sig:.076>.05) and the distribution in sampling groups was not equal, Hochberg's GT2 Post Hoc test was used. This test revealed a significant difference between science courses teachers and basic education teachers (sig:.022<.05) in terms of Content Knowledge. In addition, science courses teachers $(\bar{x}=4.35)$ find themselves more competent than other branch teachers in terms of content knowledge.

The results of the study revealed a significant difference in Technological Content Knowledge according to teachers' teaching specializations $\left(\mathrm{F}_{(3-364)}=4.94\right.$; sig:.002<.05). Since variances were not homogenously distributed (sig:.000<.05), Games-Howell Post Hoc test was used. According to the results of the test, there is a significant difference between science courses teachers and basic education teachers (sig:.016<.05). In addition, science courses teachers $(\overline{\mathrm{X}}=4.04)$ find themselves more competent than the teachers of other specializations in terms of technological content knowledge.

A significant difference was also found in Pedagogical Content Knowledge according to teachers' teaching specializations $\left(\mathrm{F}_{(3-362)=} 6.62\right.$; sig:.000<.05). Since variances were homogenously distributed (sig:.107>.05) and the distribution in sampling groups were not equal, Hochberg's GT2 Post Hoc test was used. The test showed a significant difference between science courses teachers (sig:.000<.05) and social science courses teachers (sig:.005<.05). In addition, science courses teachers $(\bar{X}=4.33)$ believe that they are more competent than the teachers of other specializations in terms of Pedagogical Content Knowledge.

There was a significant difference in Technological Pedagogical Content Knowledge according to teachers' teaching specializations $\left(\mathrm{F}_{(3-364)} 3.70\right.$; sig:.011<.05). LSD Post Hoc test was used since variances were homogenously distributed (sig:.438>.05). According to the results of the test, there is a significant difference between basic education teachers and social science courses teachers (sig:.013<.05) and science courses teachers (sig:.012<.05); also between sport-art teachers and social science courses teachers (sig:.031<.05) and science courses teachers (sig:.027<.05) in terms of Technological Pedagogical Content Knowledge. High mean scores for these specializations in other Post Hoc tests also support this finding too.

\section{Findings Regarding "Age" Variable}

One-way ANOVA was used to determine whether TPACK factors differ according to age variable. Table 6 below shows the results of the significant differences. 
Table 6. ANOVA Results regarding teachers' TPACK and age variable

\begin{tabular}{|c|c|c|c|c|c|c|c|}
\hline Factors & Age Range & Age Range & $\mathrm{n}$ & $\bar{x}$ & ss & $\mathrm{F}$ & $\mathrm{p}$ \\
\hline \multirow[t]{7}{*}{ Technology Knowledge } & \multirow[t]{4}{*}{$40-49$ years old } & & 114 & 3.53 & -- & 12.46 & -- \\
\hline & & $<30$ & 23 & 4.07 & .146 & & .001 \\
\hline & & $30-39$ & 194 & 3.87 & .075 & & .000 \\
\hline & & $>50$ & 33 & 3.37 & .127 & & .787 \\
\hline & \multirow[t]{3}{*}{$>50$ years old } & & 33 & 3.37 & -- & 12.46 & -- \\
\hline & & $<30$ & 23 & 4.07 & .174 & & .000 \\
\hline & & $30-39$ & 194 & 3.87 & .121 & & .000 \\
\hline \multirow[t]{4}{*}{ Pedagogy Knowledge } & \multirow[t]{4}{*}{$>50$ years old } & & 33 & 3.83 & -- & 5.26 & -- \\
\hline & & $<30$ & 23 & 4.14 & .138 & & .138 \\
\hline & & $30-39$ & 194 & 4.19 & .096 & & .001 \\
\hline & & $40-49$ & 114 & 4.06 & .101 & & .137 \\
\hline \multirow[t]{4}{*}{ Content Knowledge } & \multirow[t]{4}{*}{$>50$ years old } & & 33 & 4.00 & -- & 4.02 & -- \\
\hline & & $<30$ & 23 & 4.41 & .154 & & .046 \\
\hline & & $30-39$ & 194 & 4.31 & .107 & & .027 \\
\hline & & $40-49$ & 114 & 4.18 & .112 & & .538 \\
\hline \multirow{4}{*}{$\begin{array}{l}\text { Technological } \\
\text { Knowledge }\end{array}$} & \multirow[t]{4}{*}{ 40-49 years old } & & 114 & 3.80 & -- & 4.73 & -- \\
\hline & & $<30$ & 23 & 4.11 & .187 & & .139 \\
\hline & & $30-39$ & 192 & 4.02 & .146 & & .016 \\
\hline & & $>50$ & 33 & 3.74 & .153 & & .981 \\
\hline \multirow{4}{*}{$\begin{array}{l}\text { Pedagogical } \\
\text { Knowledge }\end{array}$} & \multirow[t]{4}{*}{$40-49$ years old } & & 114 & 4.07 & -- & 6.49 & -- \\
\hline & & $<30$ & 23 & 4.31 & .111 & & .138 \\
\hline & & $30-39$ & 192 & 4.30 & .069 & & .005 \\
\hline & & $>50$ & 33 & 3.96 & .145 & & .891 \\
\hline \multirow{4}{*}{$\begin{array}{l}\text { Technological } \\
\text { Knowledge }\end{array}$} & \multirow[t]{4}{*}{$>50$ years old } & & 33 & 3.67 & -- & 7.46 & -- \\
\hline & & $<30$ & 23 & 4.25 & .183 & & .014 \\
\hline & & $30-39$ & 192 & 4.13 & .161 & & .031 \\
\hline & & $40-49$ & 114 & 3.95 & .167 & & .350 \\
\hline \multirow{4}{*}{$\begin{array}{l}\text { Technological Pedagogical } \\
\text { Content Knowledge }\end{array}$} & \multirow[t]{4}{*}{$>50$ years old } & & 33 & 3.68 & -- & 8.22 & -- \\
\hline & & $<30$ & 23 & 4.21 & .178 & & .023 \\
\hline & & $30-39$ & 192 & 4.14 & .161 & & .033 \\
\hline & & $40-49$ & 114 & 3.91 & .168 & & .524 \\
\hline
\end{tabular}

There is a significant difference in teachers' Technology Knowledge $\left(\mathrm{F}_{(3-364)}=12.46\right.$; sig:.000<.05) according to their ages. Since the variances were homogenously distributed (sig:.053>.05), Hochberg's GT2 Post Hoc test was done. According to the results of the test, there was a significant difference between the teachers in 40-49 age group and who are younger than 30 years old (sig:.001<.05) and those in 30-39 age group (sig:.000<.05); and between the teachers who are older than 50 years old and those who are younger than 30 years old (sig:.000<.05) and those in 30-39 age group (sig:.000<.05). The teachers who are younger than 30 years old $(\bar{X}=4.07)$ believe that they are more competent than older teachers in terms of Technology Knowledge. 
The study found a significant difference in teachers' Pedagogy Knowledge $\left(\mathrm{F}_{(3-364)}=5.26\right.$; sig:.001<.05) according to their ages. Since the variances were homogenously distributed (sig:.117>.05), Hochberg's GT2 Post Hoc test was done. The test revealed a significant difference between the teachers who are older than 50 years old and those who are in 30-39 age group (sig:.001<.05). As for Pedagogy Knowledge, the teachers who are in 30-39 age group $(\bar{X}=4.19)$ believe that they are more competent than older teachers.

The results of the study revealed a significant difference in teachers' Content Knowledge $\left(\mathrm{F}_{(3-364)}=4.02\right.$; sig:.008<.05) according to their ages. Since the variances were homogenously distributed (sig:.480>.05), Hochberg's GT2 Post Hoc test was done. The results of the test showed a significant difference between the teachers who are older than 50 years old and those who are younger than 30 years old (sig:.046<.05) and in 30-39 age group (sig:.027<.05). As for Content Knowledge, the teachers who are younger than 30 years old $(\overline{\mathrm{X}}=4.41)$ believe that they are more competent than older teachers.

The results of the study also revealed a significant difference in teachers' Technological Content Knowledge $\left(\mathrm{F}_{(3-362)}=4.73\right.$; sig:.003<.05) according to their ages. Since the variances were not homogenously distributed (sig:.029>.05), Games-Howell Post Hoc test was done. According to the results of the test, there is a significant difference between the teachers who are in 40-49 age group and those in 30-39 age group (sig:.016<.05). As for Technological Content Knowledge, the teachers who are younger than 30 years old $(\bar{X}=4.11)$ believe that they are more competent than older teachers.

There is also a significant difference in teachers' Pedagogical Content Knowledge $\left(\mathrm{F}_{(3-362)}=6.49\right.$; sig:.000<.05) according to their ages. Games-Howell Post Hoc test was done since the variances were not homogenously distributed (sig:.001<.05). Accordingly, there is a significant difference between the teachers who are in 40-49 age group and those in 30-39 age group (sig:.005<.05). The teachers who are younger than 30 years old $(\bar{X}=4.31)$ believe that they are more competent than older teachers in terms of Pedagogical Content Knowledge.

According to the results, there is a significant difference in teachers' Technological Pedagogical Knowledge $\left(\mathrm{F}_{(3-362)}\right) 7.46$; sig:.000<.05) in terms of their ages. Since the variances were not homogenously distributed (sig:.000<.05), Games-Howell Post Hoc test was done. The results of the test revealed a significant difference between the teachers who are older than 50 years old and those who are younger than 30 years old (sig:.014<.05) and in 30-39 age group (sig:.031<.05). The teachers who are younger than 30 years old $(\bar{X}=4.25)$ believe that they are more competent than older teachers in terms of Technological Pedagogical Knowledge.

Finally, the study showed a significant difference in teachers' Technological Pedagogical Content Knowledge $\left(\mathrm{F}_{(3-362)}=8.22\right.$; sig:.000<.05) in terms of their ages. Since the variances were not homogenously distributed (sig:.000<.05), Games-Howell Post Hoc test was done and it revealed a significant difference between the teachers who are older than 50 years old and those who are younger than 30 years old (sig:.023<.05) and in 30-39 age group (sig:.033<.05). The teachers who are younger than 30 years old $(\overline{\mathrm{X}}=4.21)$ reported more competency than older teachers in terms of Technological Pedagogical Knowledge.

\section{Findings Regarding “Types of Institution” Variable}

One-way ANOVA was used to determine whether TPACK factors differ according to the type of educational institutions where the teachers worked; primary school, secondary school and high school. The results are displayed in Table 7. 
Table 7. ANOVA Results regarding teachers' Technological Pedagogical Content Knowledge and types of institution variable

\begin{tabular}{|c|c|c|c|c|c|c|c|}
\hline Factors & Variable & Variable & $\mathrm{n}$ & $\bar{x}$ & ss & $\mathrm{F}$ & $\mathrm{p}$ \\
\hline \multirow[t]{3}{*}{ Technology Knowledge } & High School & & 67 & 3.53 & -- & 6.63 & -- \\
\hline & & Secondary School & 202 & 3.84 & .104 & & .011 \\
\hline & & Primary School & 95 & 3.64 & .121 & & .622 \\
\hline \multirow[t]{3}{*}{ Pedagogy Knowledge } & Primary School & & 95 & 4.00 & -- & 4.58 & -- \\
\hline & & Secondary School & 202 & 4.19 & .069 & & .025 \\
\hline & & High School & 67 & 4.05 & .099 & & .860 \\
\hline \multirow[t]{3}{*}{ Content Knowledge } & Secondary School & & 202 & 4.33 & -- & 4.88 & -- \\
\hline & & Primary School & 95 & 4.15 & .075 & & .045 \\
\hline & & High School & 67 & 4.13 & .088 & & .071 \\
\hline \multirow{3}{*}{$\begin{array}{l}\text { Technological Content } \\
\text { Knowledge }\end{array}$} & Secondary School & & 202 & 4.01 & -- & 5.29 & -- \\
\hline & & Primary School & 95 & 3.77 & .085 & & .012 \\
\hline & & High School & 67 & 3.91 & .082 & & .472 \\
\hline \multirow{3}{*}{$\begin{array}{l}\text { Pedagogical Content } \\
\text { Knowledge }\end{array}$} & Secondary School & & 202 & 4.31 & -- & 10.04 & -- \\
\hline & & Primary School & 95 & 4.00 & .075 & & .000 \\
\hline & & High School & 67 & 4.14 & .080 & & .110 \\
\hline \multirow{3}{*}{$\begin{array}{l}\text { Technological Pedagogical } \\
\text { Knowledge }\end{array}$} & Secondary School & & 200 & 4.13 & -- & 4.99 & -- \\
\hline & & Primary School & 95 & 3.94 & .083 & & .067 \\
\hline & & High School & 67 & 3.90 & .087 & & .030 \\
\hline \multirow{3}{*}{$\begin{array}{l}\text { Technological Pedagogical } \\
\text { Content Knowledge }\end{array}$} & Secondary School & & 200 & 4.16 & -- & 10.28 & -- \\
\hline & & Primary School & 95 & 3.92 & .075 & & .004 \\
\hline & & High School & 67 & 3.82 & .085 & & .000 \\
\hline
\end{tabular}

The result of the study showed a significant difference in teachers' Technology Knowledge $\left(\mathrm{F}_{(3-364)}=6.63\right.$; sig:.001<.05) in terms of their institutions. Games-Howell Post Hoc test was done since the variances were not homogenously distributed (sig:.000<.05). The results of the test revealed a significant difference between high school teachers and secondary school teachers (sig:.011<.05). The secondary school teachers $(\overline{\mathrm{X}}=3.84)$ believe that they are more competent than primary school and high school teachers in terms of Technology Knowledge.

According to the result of the study, there is a significant difference in teachers' Pedagogy Knowledge $\left(\mathrm{F}_{33-}\right.$ ${ }_{364)}=4.58$; sig:.011<.05) in terms of their institutions. Since the variances were not homogenously distributed (sig:.001<.05), and the distribution in sampling groups was not equal, Games-Howell Post Hoc test was done. The results of the test revealed a significant difference between primary school teachers and secondary school teachers (sig:.025<.05). The secondary school teachers $(\overline{\mathrm{X}}=4.19)$ believe that they are more competent than primary school and high school teachers in terms of Pedagogy Knowledge.

According to the result of the study, there is a significant difference in teachers' Content Knowledge ( $\mathrm{F}_{(3-}$ 364) $=4.88$; sig:.008<.05) according to their institutions. Games-Howell Post Hoc test was done since the variances were not homogenously distributed $($ sig:.013<.05), and the distribution in sampling groups was not equal. According to the results of the test, there is a significant difference between primary school teachers and secondary school teachers (sig:.045<.05). The secondary school teachers $(\bar{X}=4.33)$ believe that they are more competent than primary school and high school teachers in terms of Content Knowledge. 
According to the result of the study, there is a significant difference in teachers' Technological Content Knowledge $\left(\mathrm{F}_{(3-364)}=5.29\right.$; sig:.005<.05) in terms of their institutions. Since the variances were not homogenously distributed (sig:.000<.05), and the distribution in sampling groups was not equal, GamesHowell Post Hoc test was done. The results of the test revealed a significant difference between primary school teachers and secondary school teachers (sig:.012<.05). The secondary school teachers $(\bar{X}=4.01)$ believe that they are more competent than primary school and high school teachers in terms of Content Knowledge.

The study also revealed a significant difference in teachers' Pedagogical Content Knowledge $\left(\mathrm{F}_{(3-364)}=10.04\right.$; sig:.000<.05) in terms of their institutions. Since the variances were not homogenously distributed (sig:.017<.05), and the distribution in sampling groups was not equal, Games-Howell Post Hoc test was done. The test showed a significant difference between primary school teachers and secondary school teachers (sig:.000<.05). The secondary school teachers $(\overline{\mathrm{X}}=4.31)$ believe that they are more competent than primary school and high school teachers in terms of Pedagogical Content Knowledge.

According to the results of the study, there is a significant difference in teachers' Technological Pedagogical Knowledge $\left(\mathrm{F}_{(3-364)}=4.99\right.$; sig:.007<.05) in terms of their institutions. Since the variances were not homogenously distributed (sig:.004<.05), and the distribution in sampling groups was not equal, GamesHowell Post Hoc test was done. The results of the test revealed a significant difference between secondary school teachers and high school teachers $($ sig:.030<.05). The secondary school teachers $(\bar{X}=4.13)$ believe that they are more competent than primary school and high school teachers in terms of Technological Pedagogical Knowledge.

Finally, the results showed that there is a significant difference in teachers' Technological Pedagogical Content Knowledge $\left(\mathrm{F}_{(3-364)}=10.28\right.$; sig:.000<.05) in terms of their institutions. Since the variances were homogenously distributed (sig:.077>.05), Hochberg's GT2 Post Hoc test was done. The results of the test revealed a significant difference between secondary school teachers and primary school teachers (sig:.004<.05) and high school teachers (sig:.000<.05). The secondary school teachers $(\overline{\mathrm{X}}=4.16)$ believe that they are more competent than primary school and high school teachers in terms of Technological Pedagogical Content Knowledge.

\section{Findings Regarding Technological Variables Affecting Teachers' Technological Pedagogical Content Knowledge}

The study collected data about "teachers' access to technology in their schools", "their technology use" and "whether they have received any in-service training regarding technology use". The findings are presented below.

\section{Findings Regarding "Access to Technology" Variable}

A high percentage of teachers (\%81.3) replied "Yes, I can" to the question "Can you access to technology you need in your school?" The differences for TPACK factors among teachers according to their access to technology were determined through t-test. The results showed that TPACK factors differ in terms of to what extent teachers can access to technology. The teachers who stated that they can access to technology they need in the school believed that they are competent in all TPACK factors: technology knowledge $(\bar{X}=3.78)$, pedagogy knowledge $(\bar{X}=4.16)$, content knowledge $(\bar{X}=4.30)$, technological content knowledge $(\bar{X}=3.99)$, pedagogical content knowledge $(\bar{X}=4.27)$, technological pedagogical knowledge $(\bar{X}=4.10)$ and technological pedagogical content knowledge $(\overline{\mathrm{X}}=4.09)$.

\section{Findings Regarding “Technological Competencies" Variable}

One-way ANOVA was used to determine whether TPACK factors differ according to teachers' technology use. The results are displayed in Table 8 below. 
Table 8. ANOVA Results regarding teachers' Technological Pedagogical Content Knowledge and "Technological Competencies" variable

\begin{tabular}{|c|c|c|c|c|c|c|c|}
\hline Factors & Variable & Variable & $\mathrm{n}$ & $\bar{x}$ & ss & $\mathrm{F}$ & $\mathrm{p}$ \\
\hline \multirow[t]{4}{*}{ Technology Knowledge } & Very good & & 44 & 4.60 & -- & 107.32 & -- \\
\hline & & Good & 183 & 3.85 & .065 & & .000 \\
\hline & & Medium & 130 & 3.32 & .072 & & .000 \\
\hline & Good & Medium & & & .059 & & .000 \\
\hline \multirow[t]{4}{*}{ Pedagogy Knowledge } & Very good & & 44 & 4.51 & -- & 30.35 & -- \\
\hline & & Good & 183 & 4.18 & .076 & & .000 \\
\hline & & Medium & 130 & 3.92 & .079 & & .000 \\
\hline & Good & Medium & & & .052 & & .000 \\
\hline \multirow[t]{4}{*}{ Content Knowledge } & Very good & & 44 & 4.60 & -- & 32.51 & -- \\
\hline & & Good & 183 & 4.37 & .084 & & .017 \\
\hline & & Medium & 130 & 3.99 & .087 & & .000 \\
\hline & Good & Medium & & & .057 & & .000 \\
\hline \multirow{4}{*}{$\begin{array}{l}\text { Technological Content } \\
\text { Knowledge }\end{array}$} & Very Good & & 44 & 4.60 & -- & 75.67 & -- \\
\hline & & Good & 181 & 4.05 & .060 & & .000 \\
\hline & & Medium & 130 & 3.57 & .073 & & .000 \\
\hline & Good & Medium & & & .063 & & .000 \\
\hline \multirow[t]{4}{*}{ Pedagogical Content Knowledge } & Very good & & 44 & 4.57 & -- & 34.04 & -- \\
\hline & & Good & 181 & 4.31 & .064 & & .000 \\
\hline & & Medium & 130 & 3.93 & .077 & & .000 \\
\hline & Good & Medium & & & .063 & & .000 \\
\hline \multirow{4}{*}{$\begin{array}{l}\text { Technological Pedagogical } \\
\text { Knowledge }\end{array}$} & Very good & & 44 & 4.62 & -- & 64.25 & -- \\
\hline & & Good & 181 & 4.18 & .065 & & .000 \\
\hline & & Medium & 130 & 3.71 & .073 & & .000 \\
\hline & Good & Medium & & & .060 & & .000 \\
\hline \multirow{4}{*}{$\begin{array}{l}\text { Technological Pedagogical } \\
\text { Content Knowledge }\end{array}$} & Very good & & 44 & 4.60 & -- & 46.82 & -- \\
\hline & & Good & 181 & 4.13 & .064 & & .000 \\
\hline & & Medium & 130 & 3.77 & .075 & & .000 \\
\hline & Good & Medium & & & .063 & & .000 \\
\hline
\end{tabular}

The study revealed a significant difference in teachers' Technology Knowledge $\left(\mathrm{F}_{(3-357)}=107.32\right.$; sig:.000<.05) in terms of their technological competencies. Since the variances were not homogenously distributed (sig:.023<.05), Games-Howell Post Hoc test was done. The results of the test revealed a significant difference between the teachers who label their technological competencies as "very good" and those who label it as "good" (sig:.000<.05) and those who label it as "medium" (sig:.000<.05). The teachers who define themselves as very good technology users $(\bar{X}=4.60)$ believe that they are more competent than those who define themselves as good $(\overline{\mathrm{X}}=3.85)$ and as medium $(\overline{\mathrm{X}}=3.32)$ in terms of Technology Knowledge.

According to the results of the study, there is a significant difference in teachers' Pedagogy Knowledge $\left(\mathrm{F}_{(3-}\right.$ ${ }_{357)}=30.35$; sig:.000<.05) in terms of their technological competencies. Hochberg's GT2 Post Hoc test was done since the variances were homogenously distributed (sig:.023<.05), and the distribution in sampling groups was not equal. The results of the test revealed a significant difference between all groups. Accordingly, there is a significant difference between the teachers who label their technology use as "very good" and those who label it as "medium" (sig:.000<.05) and those who label it as "medium" (sig:.000<.05), and also between 
those who define themselves as "good" and those who said that they are medium level technology users (sig:.000<.05). The teachers who define themselves as very good technology users $(\bar{X}=4.51)$ believe that they are more competent than those who define as good $(\bar{X}=4.18)$ and as medium $(\bar{X}=3.92)$ in terms of Pedagogy Knowledge.

The study also showed a significant difference in teachers' Content Knowledge $\left(\mathrm{F}_{(3-357)}=32.51\right.$; sig:.000<.05) in terms of their technological competencies. Since the variances were homogenously distributed (sig:.229>.05), and the distribution in sampling groups was not equal, Hochberg's GT2 Post Hoc test was done. The results of the test revealed a significant difference between all groups. Accordingly, there is a significant difference between the teachers who label their technology use as "very good" and those who label it as "good" (sig:.017<.05) and "medium" (sig:.000<.05); and between those who define themselves as "good" level of technology users and those who said that they are "medium" level of technology users (sig:.000<.05). The teachers who define themselves as very good technology users $(\bar{X}=4.60)$ believe that they are more competent than those who define as good $(\overline{\mathrm{X}}=4.37)$ and as medium $(\overline{\mathrm{X}}=3.99)$ in terms of Content Knowledge.

The findings of the study revealed a significant difference in teachers' Technological Content Knowledge $\left(\mathrm{F}_{(3-355)}=75.67\right.$; sig:.000<.05) in terms of their technological competencies. Games-Howell Post Hoc test was done since the variances were not homogenously distributed (sig:.000<.05). The results of the test revealed a significant difference between all groups. Accordingly, there is a significant difference between the teachers who label their technology use as "very good" and those who label it as "good" (sig:.000<.05) and "medium" (sig:.000<.05); and between those who define themselves as "medium" level of technology users (sig:.000<.05) and those who said that they are "good" technology users $($ sig:.000<.05). The teachers who define themselves as very good technology users $(\overline{\mathrm{X}}=4.60)$ believe that they are more competent than those who define as good $(\bar{X}=4.05)$ and as medium $(\bar{X}=3.57)$ in terms of Technological Content Knowledge.

The findings of the study also revealed a significant difference in teachers' Pedagogical Content Knowledge $\left(\mathrm{F}_{(3-355)}=34.04\right.$; sig:.000<.05) in terms of their technological competencies. Since the variances were not homogenously distributed (sig:.011<.05), Games-Howell Post Hoc test was done. The results of the test revealed a significant difference between all groups. Accordingly, there is a significant difference between the teachers who label their technology use as "very good" and those who label it as "good" (sig:.000<.05) and "medium" (sig:.000<.05); and between those who define themselves as "good" level of technology users and those who said that they are "medium" technology users (sig:.000<.05). The teachers who define themselves as very good technology users $(\bar{X}=4.57)$ believe that they are more competent than those who define as good $(\bar{X}=4.31)$ and as medium $(\bar{X}=3.93)$ in terms of Pedagogical Content Knowledge.

The study revealed a significant difference in teachers' Technological Pedagogical Knowledge $\left(\mathrm{F}_{(3-355)}=64.25\right.$; sig:.000<.05) in terms of their technology use. Since the variances were not homogenously distributed (sig:.015<.05), Games-Howell Post Hoc test was done. The results of the test revealed a significant difference between all groups. Accordingly, there is a significant difference between the teachers who label their technology use as "very good" and those who label it as "good" (sig:.000<.05) and "medium" (sig:.000<.05); and between those who define themselves as "good" level of technology users and those who said that they are "medium" technology users (sig:.000<.05). The teachers who define themselves as very good technology users $(\bar{X}=4.62)$ believe that they are more competent than those who define as good $(\bar{X}=4.18)$ and as medium $(\bar{X}=3.71)$ in terms of Technological Pedagogical Knowledge.

Finally, the findings of the study revealed a significant difference in teachers' Technological Pedagogical Content Knowledge $\left(\mathrm{F}_{(3-355)}=46.82\right.$; sig:.000<.05) in terms of their technology use. Since the variances were not homogenously distributed (sig:.003<.05), Games-Howell Post Hoc test was done. The results of the test revealed a significant difference between all groups. Accordingly, there is a significant difference between the teachers who label their technology use as "very good" and those who label it as "good" (sig:.000<.05) and "medium" (sig:.000<.05); and between those who define themselves as "good" technology users (sig:.000<.05) and those who said that they are "medium" technology users (sig:.000<.05). The teachers who define themselves as very good technology users $(\bar{X}=4.60)$ believe that they are more competent than those who define as good $(\bar{X}=4.13)$ and as medium $(\bar{X}=3.77)$ in terms of Technological Pedagogical Content Knowledge. 


\section{Findlings Regarding "Receiving In-Service Training" Variable}

\%68.4 of the participants replied "yes" to the question "Have you received any in-service training about technology use?". The differences in TPACK factors according to the variable "receiving in-service training programs" were determined through t-test. The results showed that all factors differ for this variable. The teachers who have received in-service training programs stated that they found themselves competent all TPACK factors: technology knowledge $(\overline{\mathrm{X}}=3.87)$, pedagogy knowledge $(\overline{\mathrm{X}}=4.21)$, content knowledge $(\overline{\mathrm{X}}$ $=4.34)$, technological content knowledge $(\overline{\mathrm{X}}=4.09)$, pedagogical content knowledge $(\overline{\mathrm{X}}=4.32)$, technological pedagogical knowledge $(\overline{\mathrm{X}}=4.14)$ and technological pedagogical content knowledge $(\overline{\mathrm{X}}=4.12)$.

\section{Findings Regarding "Educational Information Network (EIN) Use" Variable}

One-way ANOVA was done to determine whether TPACK factors differ according to teachers' EIN use. Table 9 below shows the significant results.

Table 9. ANOVA results regarding teachers' TPACK and "EIN Use" variable

\begin{tabular}{|c|c|c|c|c|c|c|c|}
\hline Factors & Variable & Variable & $n$ & $\bar{x}$ & ss & $\mathrm{F}$ & $\mathrm{p}$ \\
\hline \multirow[t]{3}{*}{ Technology Knowledge } & Regularly & & 39 & 4.17 & - & 13.31 & -- \\
\hline & & When needed & 309 & 3.70 & .090 & & .000 \\
\hline & & Never & 16 & 3.26 & .280 & & .012 \\
\hline \multirow[t]{3}{*}{ Pedagogy Knowledge } & Regularly & & 39 & 4.31 & -- & 3.27 & -- \\
\hline & & When needed & 309 & 4.09 & .087 & & .033 \\
\hline & & Never & 16 & 4.08 & .153 & & .354 \\
\hline \multirow[t]{3}{*}{ Content Knowledge } & Regularly & & 39 & 4.48 & -- & 5.27 & -- \\
\hline & & When needed & 309 & 4.23 & .095 & & .026 \\
\hline & & Never & 16 & 3.98 & .168 & & .009 \\
\hline \multirow{3}{*}{$\begin{array}{l}\text { Technological Content } \\
\text { Knowledge }\end{array}$} & Regularly & & 39 & 4.24 & -- & 5.61 & -- \\
\hline & & When needed & 309 & 3.90 & .104 & & .004 \\
\hline & & Never & 16 & 3.80 & .181 & & .047 \\
\hline \multirow{3}{*}{$\begin{array}{l}\text { Pedagogical Content } \\
\text { Knowledge }\end{array}$} & Regularly & & 38 & 4.43 & -- & 4.17 & -- \\
\hline & & When needed & 308 & 4.17 & .097 & & .024 \\
\hline & & Never & 16 & 4.04 & .168 & & .062 \\
\hline \multirow{3}{*}{$\begin{array}{l}\text { Technological Pedagogical } \\
\text { Knowledge }\end{array}$} & Regularly & & 38 & 4.21 & -- & 3.21 & -- \\
\hline & & When needed & 308 & 4.03 & .106 & & .251 \\
\hline & & Never & 16 & 3.75 & .184 & & .039 \\
\hline
\end{tabular}

The findings of the study revealed a significant difference in teachers' Technology Knowledge $\left(\mathrm{F}_{(3-364)}=13.31\right.$; sig:.000<.05) in terms of the frequency of EIN use. Since the variances were not homogenously distributed (sig:.000<.05), Games-Howell Post Hoc test was done. The results of the test revealed a significant difference between the teachers who regularly use EIN and those who use it when needed (sig:.000<.05) and those who never use it $($ sig:.012<.05). The teachers who regularly use EIN $(\overline{\mathrm{X}}=4.17)$ believe that they are more competent than those who use it when needed $(\bar{X}=3.70)$ and those who never use it $(\bar{X}=3.26)$ in terms of Technology Knowledge.

The study showed a significant difference in teachers' Pedagogy Knowledge $\left(\mathrm{F}_{(3-364)}=3.27\right.$; sig:.039<.05) in terms of the frequency of EIN use. Hochberg's GT2 Post Hoc test was done since the variances were homogenously distributed (sig:.066>.05), the distribution in sampling groups was not equal. The results of the test revealed a significant difference between the teachers who regularly use EIN and those who use 
it when needed (sig:.033<.05). The teachers who regularly use EIN $(\overline{\mathrm{X}}=4.31)$ believe that they are more competent than those who use it when needed $(\bar{X}=4.09)$ and those who never use it $(\bar{X}=4.08)$ in terms of Pedagogical Knowledge.

According to the study, there is a significant difference in teachers' Content Knowledge $\left(\mathrm{F}_{(3-364)}=5.27\right.$; sig:.006<.05) in terms of the frequency of EIN use. Since the variances were homogenously distributed (sig:.094>.05) and the distribution in sampling groups was not equal, Hochberg's GT2 Post Hoc test was done. The results of the test revealed a significant difference between the teachers who regularly use EIN and those who use it when needed (sig:.026<.05) and those who never use it (sig:.009<.05). The teachers who regularly use EIN $(\bar{X}=4.48)$ believe that they are more competent than those who use it when needed $(\bar{X}=4.23)$ and those who never use it $(\bar{X}=3.98)$ in terms of Content Knowledge.

The results of the study revealed a significant difference in teachers' Technological Content Knowledge $\left(\mathrm{F}_{(3-364)}=5.61\right.$; sig:.004<.05) in terms of the frequency of EIN use. Since the variances were homogenously distributed (sig:.226>.05) and the distribution in sampling groups was not equal, Hochberg's GT2 Post Hoc test was done. According to the results of the test, there is a significant difference between the teachers who regularly use EIN and those who use it when needed (sig:.004<.05) and those who never use it (sig:.047<.05). The teachers who regularly use EIN $(\overline{\mathrm{X}}=4.24)$ believe that they are more competent than those who use it when needed $(\bar{X}=3.90)$ and those who never use it $(\bar{X}=3.80)$ in terms of Technological Content Knowledge.

The study also showed a significant difference in teachers' Pedagogical Content Knowledge $\left(\mathrm{F}_{(3-362)}=4.17\right.$; sig:.016<.05) in terms of the frequency of educational information network use. Hochberg's GT2 Post Hoc test was done since the variances were homogenously distributed (sig:.075>.05) and the distribution in sampling groups was not equal. The results of the test showed a significant difference between the teachers who regularly use EIN and those who use it when needed (sig:.024<.05). The teachers who regularly use EIN $(\bar{X}=4.43)$ believe that they are more competent than those who use it when needed $(\bar{X}=4.17)$ and those who never use it $(\overline{\mathrm{X}}=4.04)$ in terms of Pedagogical Content Knowledge.

Finally, the results of the study revealed a significant difference in teachers' Technological Pedagogical Content Knowledge $\left(\mathrm{F}_{(3-362)}=3.21\right.$; sig:.041<.05) in terms of the frequency of EIN use. Since the variances were homogenously distributed (sig:.440>.05) and the distribution in sampling groups was not equal, Hochberg's GT2 Post Hoc test was done. The results of the test revealed a significant difference between the teachers who regularly use EIN and those who never use it (sig:.039<.05). The teachers who regularly use $\operatorname{EIN}(\bar{X}=4.21)$ believe that they are more competent than those who use it when needed $(\bar{X}=4.03)$ and those who never use it $(\bar{X}=3.75)$ in terms of Technological Pedagogical Content Knowledge.

\section{DISCUSSION AND CONCLUSION}

The study revealed that teachers find themselves competent in terms of TPACK factors. According to the means of TPACK sub factors, the teachers believed that they are competent the most in content knowledge $(\bar{X}=4.25)$ and the least in technology knowledge $(\bar{X}=3.74)$. The analyses of TPACK factors for demographic, technological and EIN use variable also revealed significant differences.

Age variable, which is a demographic factor, is significantly different only for technology knowledge. Male teachers believe that they have better technology knowledge than female ones, which implies that female teachers need more support for technology knowledge.

As for teaching specialization variable, significant differences were found between science courses teachers, basic education and sports-arts teachers. Because of low mean scores of basic education and sports-arts teachers for TPACK factors when compared to social science courses and science courses teachers, the first group teachers should be supported so that they can develop technological competencies.

As for "age" variable, we can conclude that the teachers who are older than 50 years old differ in TPACK factors more than younger teachers. Especially, the teachers who are 40 years old and above differ when compared to younger teachers in terms of technology knowledge. The teachers who are in 40-49 age group and older than 50 years old had lower means in all TPACK factors than younger teachers, which implies that in-service training programs should be implemented to develop technological competencies of older age groups. 
As for the grouping of teachers according to educational institution type, the study found significant differences between secondary school teachers and primary and high school teachers in TPACK factors. The secondary school teachers had higher means than other groups of teachers in all TPACK factors and this finding should be examined in more detail in further studies.

The comparison of the statements related to technology with TPACK factors showed that the teachers' access to technology differed in all TPACK factors. The teachers who stated that they can access to technology in their schools believe that they are more competent in TPACK factors than those who stated that they cannot. The teachers who are interested in technology are more likely to develop quality teaching materials, learn about pedagogies suitable for new environments and improve their competencies in all TPACK fields. The findings which support this finding is that there are significant differences between the means of teachers who define their technology use as "medium" "good" and "very good" in terms of TPACK factors. As technology use level increases, TPACK competencies increase. This finding shows that improvement of teachers in terms of pedagogy and content should be based on and integrated with technology use. Another item in the study was whether "the teachers have received any in-service training about technology use or not". The responses provided for this item showed that those who have received this kind of in-service training significantly differed from those who have not in terms of all TPACK factors and had higher means, which indicates higher TPACK competencies.

The frequency of teachers' EIN use was classified as "never" "when needed" and "regularly". When this classification was examined in relation to TPACK factors, it was found that there was a significant difference between the teachers who use EIN regularly and those who use it when needed and those who never use it in terms of the following TPACK factors: Technology Knowledge, Content Knowledge, and Technological Content Knowledge. Similarly, the teachers who are regular users of EIN significantly differ from those who use it when needed in Pedagogy Knowledge and Pedagogical Content Knowledge. Accordingly, we can conclude that technology knowledge is a determining factor in EIN use. Indeed, the regular users of EIN had higher means scores for all TPACK factors, which implies that they find themselves more competent than others.

Finally, this study revealed that "access to technology", "technology use level" and "receiving in-service training about technology" have significant effects on TPACK factors. The teachers who find themselves competent in technology also find themselves competent in terms of technology, content, pedagogy, technological content, technological pedagogical and technological pedagogical content. Accordingly, increasing teachers' competencies in above mentioned issues will have positive effects on their content and pedagogy knowledge and contribute to their development by combining their technology, content and pedagogy knowledge. Consequently, distance and technology-based educational environments such as EIN will be more effective, and more people will benefit from these new educational environments in the future.

\section{BIODATA and CONTACT ADDRESSES of AUTHORS}

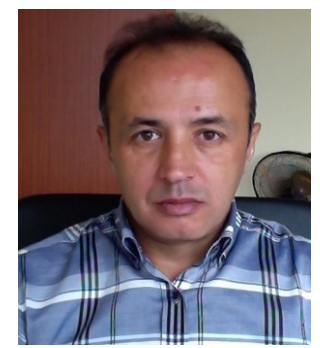

Dr. Kamil CEKEROL is a faculty member of the Anadolu University Open Education Faculty, Department of Distance Education. He graduated from the Anadolu University Faculty of Economics and Administrative Sciences, Department of Economics in 1990. Then he received his master's and $\mathrm{PhD}$ degrees in Economics from Anadolu University. He carried out his academic studies on distance education and continues. His research interest are distance education politics, learner support systems in distance education and administrative structures in distance education.

Kamil CEKEROL

Department of Distance Education, Open Education Faculty

Address: Anadolu University, Eskisehir, TURKEY

Phone: +90 2223350580 ext: 2678

E-mail: kcekerol@anadolu.edu.tr 


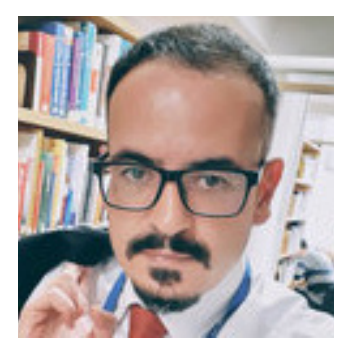

Emin OZEN is a $\mathrm{PhD}$ candidate Open and Distance Education at Open Education Faculty, Anadolu University. His academic interest areas are digital transformation, education computing network, digital data, technology, open and distance learning, e-learning, teaching and learning, technology education. He has 2 journal articles published; 4 international conference papers submitted to international meetings. Since 2008, the Republic of Turkey Ministry of Education is working in affiliation. He is currently teaching Mathematics.

\section{Emin OZEN}

Department of Distance Education, Graduate School of Social Sciences

Address: Anadolu University, Eskisehir, TURKEY

Phone: +90 5066892582

E-mail: eminozen@anadolu.edu.tr

\section{REFERENCES}

Akyuz, H. I., Pektas, M., Kurnaz, M. A., ve Memis, E. K. (2014). Akilli tahta kullanimli mikro ogretim uygulamalarinin fen bilgisi ogretmen adaylarinin TPAB'larina ve akilli tahta kullanima yonelik algilarina etkisi [The effect of smart board centered micro-teaching activities on science teachers' technological pedagogical content knowledge (TPCK) and their perceptions towards using smart board]. Cumburiyet International Journal of Education, 3(1), 1-14.

Alkan, C. (1998). Egitim teknolojisi [Education technology] (6th Edition). Ankara: Ani Publications.

Ay, Y. (2015). Ogretmenlerin teknolojik pedagojik alan bilgisi (TPAB) becerilerinin uygulama modeli baglaminda degerlendirilmesi [Evaluation of teachers' technological pedagogical content knowledge (tpack) within the framework of practical model]. (Doctoral dissertation). Eskisehir Osmangazi University Graduate School of Educational Sciences, Eskisehir, Turkey. Available from http://hdl.handle.net/11684/361

Ay, Y., Karadag, E., \& Acat, M.B. (2015). The technological pedagogical content knowledge-practical (TPACK- Practical) model: Examination of its validity in the Turkish culture via structural equation modeling. Computers \& Education, 88, 97-108.

Bagdiken, P., \& Akgunduz, D. (2018). Fen bilimleri ogretmenlerinin teknolojik pedagojik alan bilgisi ozguven duzeylerinin incelenmesi [An investigation of science teachers' technological pedagogical content knowledge self confidence levels]. Gazi Universitesi Gazi Egitim Fakultesi Dergisi [Gazi University Journal of Gazi Educational Faculty], 38(2), 535-566.

Balcin, M.D., \& Ergun, A. (2018). Fen bilgisi ogretmen adaylarinin sahip olduklari teknolojik pedagojik alan bilgisi (TPAB) ozyeterliliklerinin belirlenmesi ve cesitli degiskenlere gore incelenmesi [Determination of technological pedagogical content knowledge (TPACK) self-efficacy of science teacher candidates and analysis of them according to various variables]. Mehmet Akif Ersoy Universitesi Egitim Fakultesi Dergisi [Mehmet Akif Ersoy University Journal of Faculty of Education], 45, 23-47.

Baris, M.F. (2015). Universite ogrencilerinin uzaktan ogretime yonelik tutumlarinin incelenmesi: Namik Kemal Universitesi ornegi [Analyzing the university students' attitudes towards distance education: Namik Kemal University case study]. Sakarya University Journal of Education, 5/2, 36-46.

Buyukozturk, S., Kilic Cakmak, E., Akgun, O. E., Karadeniz, S., \& Demirel, F. (2012). Bilimsel arastirma yontemleri [Scientific research methods] (11th Edition). Ankara: PegemA Publications.

Canbolat, N. (2011). Matematik ogretmen adaylarinin teknolojik pedagojik alan bilgileri ile dusunme stilleri arasindaki iliskinin incelenmesi [A research on the interaction between technological pedagogical content knowledge and thinking styles of mathematics teacher candidates]. (Master's dissertation). Selcuk University Graduate School of Educational Sciences, Konya, Turkey. Available from http:// hdl.handle.net/123456789/1954 
Horzum, M.B., Akgun, O.E., Ozturk E. (2014). The psychometric properties of the technological pedagogical content knowledge scale. International Online Journal of Educational Sciences, 6(3), 544-557.

Karadeniz, S., \& Vatanartiran, S. (2015). Sinif ogretmenlerinin teknolojik pedagojik alan bilgilerinin incelenmesi [Primary school teachers' technological pedagogical content knowledge]. Elementary Education Online, 14(3), 1017-1028.

Kartal, T., Kartal, B., \& Uluay, G. (2016). Technological pedagogical content knowledge self assessment scale (TPACK-SAS) for pre-service teachers: Development, validity and reliability. IJOESS, 7(23), $1-36$.

Kilic, S. (2013). Ornekleme yontemleri [Sampling Methods]. Journal of Mood Disorders, 3(1), 44-6.

Koehler, M.J. \& Mishra, P. (2008). Introducing TPCK. In D.Stoilescu, D.E.McDougall (Eds.), The handbook of technological pedagogical content knowledge (TPCK) for educators (pp. 3-29). AACTE Committee on Innovation and Technology. NY: Routledge/Taylor \& Francis Group.

Koehler, M.J., Mishra, P., \& Yahya, K. (2007). Tracing the development of teacher knowledge in a design seminar: Integrating content, pedagogy and technology. Computers \& Education, 49(3), 740-762.

Onal, N. (2016). Development, validity and reliability of TPACK scale with pre-service mathematics teachers. International Online Journal of Educational Sciences, 8(2), 93-107.

Ozen, E. (2019). Egitimde guncel egilimler ve egitim bilisim agi [Current trends in education and education information network]. In T. Mehmetoglu, \& Z.Sakhi (Eds.) Zeugma II. International Multidisciplinary Studies Congress, 2019 (pp. 2070-2085). Iksad Publications.

Perkmen, S. \& Tezci, E. (2011). Egitimde teknoloji entegrasyonu: Materyal gelistirme ve coklu ortam tasarimi [Technology integration in education: Material development and multiple media design]. Ankara: Pegem Akademi Publications.

Shulman, L. S. (1986). Those who understand: Knowledge growth in teaching. Educational Researcher, 15(2), 4-14.

Teo, T., Ursavas, F. O., \& Bahcekapili, E. (2012). An assessment of pre-service teachers' technology acceptance in Turkey: A structural equation modeling approach. The Asia-Pacific Education Researcher, 21(1), 191-202.

Temizyurek, D., Unlu, O. (2015). Dil ogretiminde teknolojinin materyal olarak kullanimina bir ornek: "Flipped classroom" [The use of technology in language teaching material as an example: "Flipped classroom"]. Bartin University Journal of Faculty of Education, 4(1), 64-72. Retrieved from https://dergipark.org.tr/tr/pub/buefad/issue/3816/51248

Yarar, G. (2018). Ingilizce ogretim elemanlarinin teknolojik pedagojik alan bilgilerinin bazi degiskenler acisindan degerlendirilmesi: Ankara ili ornegi [Assessment of technological pedagogical knowledge of english instructors in terms of some variables: Ankara province example]. Uluslararasi Sosyal Arastirmalar Dergisi [The Journal of International Social Research], 11(57), 455-468. http://dx.doi. org/10.17719/jisr.2018.2464

Yilmaz, G.K. (2015). Analysis of technological pedagogical content knowledge studies in Turkey: a metasynthesis study. Education and Science. 40(178), 103-122. 